\title{
Microbial Assessment and Prevalence of Foodborne Pathogens in Natural Cheeses in Japan
}

\author{
Firew Kassa Esho, Budbazar Enkhtuya, Akiko Kusumoto, and Keiko Kawamoto \\ Section of Food Microbiology and Immunology, Research Center for Animal Hygiene and Food Safety, \\ Obihiro University of Agriculture and Veterinary Medicine Inada-cho, Obihiro, Hokkaido 080-8555, Japan \\ Correspondence should be addressed to Keiko Kawamoto; kkeiko@obihiro.ac.jp
}

Received 29 October 2013; Accepted 4 December 2013

Academic Editor: Hiroshi Asakura

Copyright (C) 2013 Firew Kassa Esho et al. This is an open access article distributed under the Creative Commons Attribution License, which permits unrestricted use, distribution, and reproduction in any medium, provided the original work is properly cited.

\begin{abstract}
The production and consumption of domestic natural cheese in Japan is increasing year by year. More than ninety percent of domestic natural cheese is produced in Hokkaido region of Japan, while information on its quality and safety related to foodborne pathogens is limited. To assess the microbiological safety of domestic natural cheese, a total of 126 natural cheese samples produced in Hokkaido were collected from December, 2012, to July, 2013. In addition to standard plate count (SPC) and coliform counts, the prevalence study of three pathogens (Listeria monocytogenes, pathogenic Escherichia coli, and Salmonella spp.) was performed on each sample. Real-time PCR and matrix-assisted laser desorption-ionization time-of-flight mass spectrometer methods were employed for identification of presumptive pathogens. Coliform was detected in 25 samples (19.8\%) with a minimum of $25 \mathrm{cfu} / \mathrm{g}$ and a maximum of more than $3.0 \times 10^{6} \mathrm{cfu} / \mathrm{g}$. Salmonella spp. and L. monocytogenes were not isolated from any of the samples. Only one sample $(0.80 \%)$ showed positive PCR amplification for ipaH gene suggesting possible contamination of enteroinvasive E. coli or Shigella in this product. Overall results indicate that natural cheeses produced in Hokkaido region were satisfactory microbiological quality according to existing international standards.
\end{abstract}

\section{Introduction}

Cheese consumption became popular in Japanese culinary system following the exposure of public to the western food cultures, which lead to substantial increase in domestic production and imports $[1,2]$. Although the Japanese cheese market relies on imports by nearly $80 \%$, domestic production of natural cheese is growing year by year. A recent estimate shows that over 50,000 metric tons of natural cheese is produced in Japan per year [2] out of which the majority comes from Hokkaido region. Production of natural cheese in this region accounts for more than $90 \%$ of the overall domestic production. The number of farm dairies producing natural cheese is doubled in a decade.

Consumption of cheese has been associated with foodborne outbreaks in reports from different parts of the world raising the safety concern of the product [3]. Listeria monocytogenes is a ubiquitous foodborne pathogen and human listeriosis outbreaks are often associated with ready-to-eat food products including cheese. Ingestion of foods contaminated with this pathogen results in a severe disease with higher fatality rate where certain risk groups including pregnant, newborn, elderly people, and immunocompromised patients are affected [4]. Several outbreaks and sporadic cases of disease associated with the consumption of pasteurized milk, cheeses made from unpasteurized milk, and other dairy products in USA and Europe in the past decades [3, 5-10]. Previous domestic studies from 1992 to 1994 reported that L. monocytogenes contamination was found in raw milk [11]. However, a foodborne listeriosis outbreak was occurred in 2001 due to contaminated natural cheese [12]. This is the first and only reported foodborne listeriosis in Japan so far.

In addition to L. monocytogenes, other enteric pathogens such as Shiga toxin-producing Escherichia coli (STEC) and Salmonella are also the causes of concern on public health in relation to the consumption of cheese worldwide $[3,5-10]$. STEC is another important foodborne pathogens responsible for outbreaks which may result in hemorrhagic colitis (HC) 
and lethal hemolytic uremic syndrome (HUS) [13]. Although most outbreaks of HC and HUS have been attributed to serotype O157:H7, infections are also caused by other serotypes, such as O26:H11, O103:H2, O111:H8, and O145:H28 $[8,10]$. Salmonella is another important organism which represents well-recognized foodborne bacterial pathogens. It causes a number of illnesses and deaths worldwide.

Natural cheeses, regardless of their varying characteristics, can support the growth of microorganisms including foodborne pathogens. Given the continuous increase of natural cheese consumption and following earlier reported outbreak of L. monocytogenes in Hokkaido associated with cheese [12], there is concern for microbiological safety of domestically produced natural cheeses. The purpose of this study was to assess a hygienic quality and safety of natural cheeses produced in Hokkaido, Japan. We performed standard plate counts (SPC) and coliform counts on each sample to obtain general hygienic information. Since a survey targeting other important pathogens in domestic natural cheese has not been performed yet, the prevalence of three significant pathogens such as Salmonella spp., pathogenic E. coli, and L. monocytogenes was also examined in this study.

\section{Materials and Methods}

2.1. Sample Collection. A total of 126 domestic natural cheeses made from raw cows' milk were collected from local retail stores and farmers' markets in Hokkaido, Japan, from December 2012 to July 2013. Some samples were obtained from online source. Sampling was centered in the Eastern Hokkaido because many natural cheese producers are located in this area, and most of cheese samples used in this study were produced on farm-dairies. The samples included soft type $(n=66)$ those were mostly ripened, semihard $(n=33)$, and hard type $(n=27)$ of cheeses. Samples were stored at refrigeration temperature $\left(4\right.$ to $8^{\circ} \mathrm{C}$ ) during delivery to the laboratory. Cheese type, producing companies, expiry dates, and packaging were recorded and the samples were stored in refrigerator until examined within the shelf life.

2.2. Bacterial Count. The homogenates of samples were prepared by aseptically removing $25 \mathrm{~g}$ of cheese into sterile strainer/filter-stomaching bags (Filterbag type P, GSI Creos Corporation, Tokyo, Japan). A $225 \mathrm{~mL}$ of buffered peptone water (BPW) was also added into the stomaching bags containing the samples and homogeneously mixed in pulsed stomacher (AES Laboratoire, Combourg, France) twice for $30 \mathrm{sec}$. The sample homogenates were serially diluted with BPW. Each serial dilution of sample homogenates was pourplated on SPC agar (OXOID, Basingstoke, UK) and Deoxycholate agar (MERCK and Eiken Chemical, Tokyo, Japan) for SPC and coliform, respectively, followed by incubation of the plates at $37^{\circ} \mathrm{C}$ for $48 \mathrm{~h}$.

2.3. Detection of Pathogens. Isolation of L. monocytogenes was conducted as described in International Organization for Standardization ISO 11290-1 [14]. In brief, $25 \mathrm{~g}$ of samples were preenriched in $225 \mathrm{~mL}$ of half Frazer broth (OXOID) and incubated for $24 \mathrm{~h}$ at $30^{\circ} \mathrm{C}$. From preenriched sample, $0.1 \mathrm{~mL}$ of culture was enriched in $10 \mathrm{~mL}$ of Fraser broth (OXOID) and incubated at $35^{\circ} \mathrm{C}$ for $48 \mathrm{~h}$. Then, a loopful of the cultures were streaked on PALCAM agar (OXOID) and incubated at $37^{\circ} \mathrm{C}$ for $48 \mathrm{~h}$. Typical or suspect colonies were picked up, streaked on BHI agar (Becton Dickinson, NJ, USA), and incubated at $37^{\circ} \mathrm{C}$ for $24 \mathrm{~h}$ for further identification.

Isolation of Salmonella spp. was carried out following the procedures indicated in US Food and Drug Administration (FDA) Bacteriological Analytical Manual Online [15]. Briefly, $25 \mathrm{~g}$ of samples was preenriched in $225 \mathrm{~mL}$ buffered peptone water (MERCK) and incubated at $35^{\circ} \mathrm{C}$ for $18 \mathrm{~h}$. Next, $0.1 \mathrm{~mL}$ of each sample homogenate was enriched into $10 \mathrm{~mL}$ of Rappaport-Vassiliadis (RV) broth (OXOID) and incubated at $42^{\circ} \mathrm{C}$ for $18 \mathrm{~h}$. Then, a loopful of RV culture was streaked on deoxycholate hydrogen sulfide lactose agar (DHL; Eiken Chemical) and CHROMagar Salmonella and incubated at $37^{\circ} \mathrm{C}$ for $24 \mathrm{~h}$. Suspicious colonies were collected and streaked on BHI agar for further analysis by Matrixassisted laser desorption-ionization time-of-flight mass spectrometer (MALDI-TOF MS).

Screening for pathogenic E. coli (STEC, enterotoxigenic E. coli, enteropathogenic E. coli, enteroaggregative E. coli, and enteroinvasive $E$. coli) was performed by real-time PCR based on their associated genetic markers. Briefly, $25 \mathrm{~g}$ of samples was preenriched in $225 \mathrm{~mL}$ of $\mathrm{mEC}$ broth with novobiocin (MERCK) and incubated at $37^{\circ} \mathrm{C}$ for $24 \mathrm{~h}$. DNA was extracted from $2 \mathrm{~mL}$ of preenriched broth by using PrepMan Ultra Sample Preparation kit (Applied Biosystems, Foster City, CA, USA). Real-time PCR was performed using QuickPrimer kit (stx 1, stx 2, ipaH, LT, EASTI, STI) (Takara Bio, Shiga, Japan) according to the manufacturer's instruction. QuickPrimer Control DNA sets were used as positive control while DDW was used as negative control of the DNA amplification.

2.4. Identification of Bacteria by MALDI-TOF MS. MALDITOF MS analysis was used to identify presumptive isolates. Bacterial cells of single colony grown on BHI agar plates were transferred to a 96 well stainless steel target plate (Bruker Daltonik, Germany) using a disposable loop. The sample on the plate was then overlaid with $1 \mu \mathrm{L}$ of $\alpha$ Cyano-4-hydroxycinnamic acid and allowed to dry at room temperature. The plate was then subjected to MALDI-TOF Mass Spectrometer machine (autoflex-04S, Bruker Daltonik) and profile spectra were analyzed using MALDI Biotyper 2.0 software (Bruker Daltonik) according to the reference database.

\section{Result}

Amongst the total samples inspected (126 samples), 66, 33 , and 27 of them were soft, semihard, and hard type of cheeses, respectively. All natural cheese samples in this study was already precut and prepacked individually at the time of purchase. Soft cheeses tested (66 samples) include brie, camembert, cream cheese, gorgonzola, mozzarella, and washtype soft cheeses. Semi-hard (33 samples) and hard type 
TABLE 1: Coliform-positive rates in the different types of cheese and packaging.

\begin{tabular}{|c|c|c|c|c|c|c|c|c|}
\hline \multirow{2}{*}{ Cheese types } & \multicolumn{7}{|c|}{ Package types (\% of coliform positive) } & \multirow{2}{*}{ Total } \\
\hline & AF/other ${ }^{\mathrm{a}}$ & Paper $A^{b}$ & Paper $B^{c}$ & Plastic $\mathrm{A}^{\mathrm{d}}$ & Plastic $\mathrm{B}^{\mathrm{e}}$ & Plastic $C^{f}$ & Can & \\
\hline Soft & $1 / 5(20.0)$ & $5 / 5(100.0)$ & $7 / 22(31.8)$ & $3 / 16(18.8)$ & $2 / 8(25.0)$ & $0 / 9(0.0)$ & $0 / 1(0.0)$ & $18 / 66(27.3)$ \\
\hline Semi-hard & 0 & 0 & 0 & $3 / 32(9.4)$ & $0 / 1(0)$ & 0 & 0 & $3 / 33(9.1)$ \\
\hline Hard & 0 & 0 & 0 & $4 / 27(14.8)$ & 0 & 0 & 0 & $4 / 27(14.8)$ \\
\hline Total & $1 / 5(20.0)$ & $5 / 5(100.0)$ & $7 / 22(31.8)$ & $10 / 75(13.3)$ & $2 / 9(22.2)$ & $0 / 9(0.0)$ & $0 / 1(0.0)$ & $25 / 126(19.8)$ \\
\hline
\end{tabular}

${ }^{a}$ Primary packaging: aluminum foil wrap, secondary: none, plastic bag or wooden box.

${ }^{\mathrm{b}}$ Paper wrapping only.

${ }^{\mathrm{c}}$ Primary packaging: paper, secondary: carbon box, wooden box or plastic bag.

${ }^{\mathrm{d}}$ Plastic vacuum seal.

${ }^{\mathrm{e}}$ Plastic film wrapping.

${ }^{\mathrm{f}}$ Plastic container.

cheese (27 samples) samples include cheddar, caciocavallo, emmental, gouda gruyere, and raclette.

SPC of natural cheese tested in this study ranged from below detection limit $(<10 \mathrm{cfu} / \mathrm{g})$ to $6.4 \times 10^{6} \mathrm{CFU} / \mathrm{g}$ (Figure 1(a)). Five (4.0\%) out of 126 samples were negative $(<10 \mathrm{cfu} / \mathrm{g})$ for viable aerobic bacteria. SPC counts are generally used for monitoring microbial quality and spoilage levels. However, fermented products like cheese generally show high number of SPC because "good" microorganisms present in food to ferment properly. High level of SPC in natural cheese samples seems to be natural, since some lactic bacteria and mold are known to grow on SPC agar.

No coliforms were detected in $80.2 \%$ of samples tested in this study, and 25 of cheese samples $(19.8 \%)$ were found to be positive for coliform bacteria (Table 1). Coliform counts ranged from below detection limit $(<10 \mathrm{cfu} / \mathrm{g})$ to over detection limit $\left(>3.0 \times 10^{6} \mathrm{CFU} / \mathrm{g}\right)$ (Figure $\left.1(\mathrm{~b})\right)$.

Soft type cheese showed the highest positivity of coliform compared to other cheese types. Out of the total 66 soft cheese samples, 18 samples (27.3\%) were positive for coliform with minimum and maximum values of $2.8 \times 10^{1}$ and more than $3.0 \times 10^{6} \mathrm{CFU} / \mathrm{g}$, respectively. On the other hand, from the 33 semi-hard types of cheese samples, $9.1 \%$ of them were positive for coliform with minimum and maximum values of $8.0 \times 10^{2}$ and $8.0 \times 10^{5} \mathrm{CFU} / \mathrm{g}$, respectively. Among 27 samples of hard type cheese, four samples (14.8\%) were positive for coliform count with minimum and maximum values of $2.5 \times 10^{1}$ and $2.7 \times 10^{4} \mathrm{CFU} / \mathrm{g}$, respectively.

We further classified the type of packaging into 7 types such as AF/other (primary packaging: aluminum foil wrapping, secondary: none, plastic bag or wooden box), Paper A (paper wrapping only), Paper B (primary: paper, secondary: carbon box, wooden box or plastic bag), Plastic A (plastic vacuum seal), Plastic B (plastic film wrapping), Plastic C (plastic container), and Can (canned). Table 1 shows the relatedness between coliform contamination and cheese and packaging types. As shown in this Table, various packagings were applied for soft cheeses, whereas most of semi-hard and hard type cheeses were plastic vacuum sealed. Soft type cheeses wrapped with paper (Paper A in Table 1) showed the highest coliform-positive rate such as $100.0 \%$. Although the number of samples were as low as 5 , this is a notable difference compared to the other packagings. The prevalence of coliform

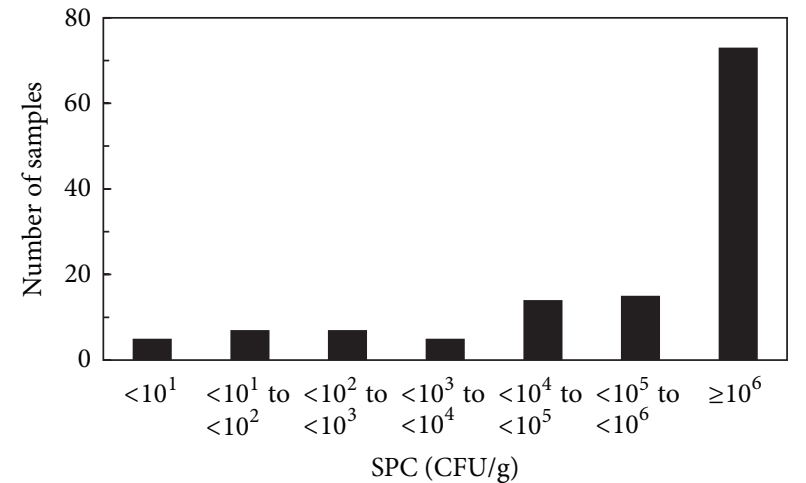

(a)

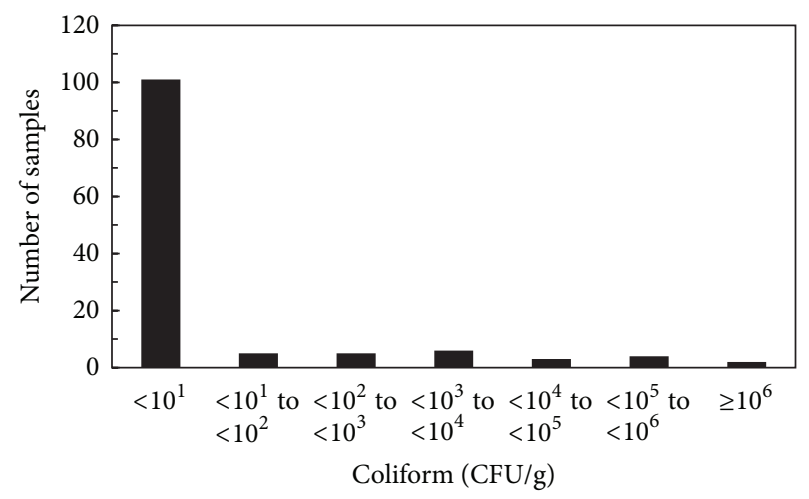

(b)

FIGURE 1: Hygienic quality of natural cheese samples. Distribution of SPC (a) and coliform counts (b) in natural cheese samples.

in soft cheeses that were paper-wrapped but also employed secondary outer packaging such as carbon box, wooden box, or plastic bags (Paper B in Table 1) showed lower contamination. Coliform-positive rate of plastic packaging including film wrapping $(25.0 \%)$, vacuum seal $(18.8 \%)$, and container (0.0\%) were much lower compared to paper wrapping.

For detection of pathogens, we used standard analytical methods of ISO and FDA as well as Japanese method of Ministry of Health, Labor and Welfare (MHLW). For identification of presumptive isolates, we used MALDI-TOF MS analysis and real-time PCR analysis. The result showed that 
among the 126 samples tested for L. monocytogenes none of them was positive for this pathogen. Likewise, no Salmonella spp. was detected from 126 natural cheese samples. However, under real-time PCR inspection, none of the 126 samples inspected was positive for pathogenic E. coli, except one sample $(0.79 \%)$ that showed positive result for ipaH gene, indicating possible presence of EIEC or Shigella spp. [16]. However, we failed to isolate the pathogen from the cheese sample by culture-based detection method using specific media for Shigella spp.

\section{Discussion}

Despite the growing popularity of domestic natural cheeses among consumers, information about microbiological safety of these products is limited. The incidence of high coliform count in food is considered as indicator for reduced hygienic condition in production process. The results of this study shows that about $80.2 \%$ of the 126 natural cheese samples examined were negative for coliforms. Although microbiological criteria for L. monocytogenes in natural cheese (negative per $25 \mathrm{~g}$ ) are described by the Ministry of Health, Labour and Welfare, other criteria, for example, coliform count, E. coli, and the other pathogenic bacteria, are not specified. However, it is a prerequisite to use pasteurized milk for natural cheese production in Japan. In case of using unpasteurized raw milk, producers must process products under equivalent temperature condition $\left(63^{\circ} \mathrm{C}\right.$ for $\left.30 \mathrm{~min}\right)$ to eliminate the risk of pathogenic organisms (Ministry of Health, Labour and Welfare, 2003). Thus, coliform bacteria are not expected to exist due to the heating process in the production of natural cheese. Although milk pasteurization is regarded as an effective method to eliminate bacteria including foodborne pathogens, it is suggested that postpasteurization contamination and poor hygienic practices such as inappropriate pasteurization of raw milk and equipment also one of the causative factor in cheese-related foodborne illness [17].

The present study revealed significant correlation between packaging type and rate of coliform contamination in soft type cheese as a results of their packaging in paper with or without of secondary packaging (31.8\% and $100.0 \%$ resp.), plastic packaging by film wrapping, vacuum or container $(25.0 \%, 18 / 8 \%$ and $0.0 \%$ resp.), aluminum foil $(20.0 \%)$ and canned $(0.0 \%)$. The microbiological quality of natural cheese is influenced by equipment and environmental hygiene during production, packaging and handling and storage conditions as well as by the quality of raw milk. It was not determined in this study whether the highest coliform prevalence in paper-wrapped cheese is due to pre-packaging or post-packaging. However, our results clearly indicate that appropriate packaging such as plastic packaging and/or combination of primary and secondary packaging will reduce the risk of contamination. To choose an appropriate packaging that is suitable for the products is a simple and practical measure to reduce the risk of unnecessary contamination and ensure the food safety. We are planning to discuss about our data with the relevant cheese manufacturers whose products were observed in the high levels or continuous contamination of coliform during the survey for making a good hygiene practice plan and appropriate HACCP plan, by collecting and analyzing the data of coliform contamination levels in pre-and post production process including raw milk, pasteurization, factory environment such as utensils and equipment, storage and ripened shelf, and packaging materials, and so forth.

Most of the natural cheese samples tested in this study complied with the microbiological criteria by Hokkaido regional accreditation body, which is the food standard (criteria) uniquely given by Hokkaido Government. Since Hokkaido prefecture is the nation's first and largest area in the production of a wide array of agricultural, seafood and fresh dairy products including natural cheese (Spotlight on Hokkaido, NatureJobs article in 2011), ensuring food safety of the food products those made in Hokkaido region is the one of the important issues. Hokkaido regional accreditation requires natural cheese to be negative for coliform and L. monocytogenes in $25 \mathrm{~g}$ by the standard microbiological test (http://www.dairyfoodsconsulting.com/pdf/EU_cheese safety_report.pdf). Similarly, the natural cheese samples tested in this study were within the limit of US ordinance for pasteurized grade "A" milk which states coliform should be lower than $10 \mathrm{cfu} / \mathrm{mL}$ [18]. Applying criteria in the European standard that requires coliform in cheese produced from heat-treated milk to be less than or equal to $10^{5} \mathrm{cfu} / \mathrm{g}$ [16], $95.2 \%$ of samples inspected in this study were within this limit.

The prevalence of foodborne pathogens including $L$. monocytogenes, pathogenic E. coli (STEC, ETEC, EPEC, EAEC, and EIEC), and Salmonella spp. in natural cheese was investigated in this study. L. monocytogenes, STEC, and Salmonella are reportedly associated with foodborne outbreaks related to the consumption of cheese $[3,5-10]$. Apart from the single one, all the other samples inspected had no prevalence of the foodborne pathogens such as L. monocytogenes, Salmonella spp., and pathogenic E. coli. The results of the present study also demonstrate that natural cheeses produced in Hokkaido are negative for these relatively frequent foodborne pathogens of the recent times. The ipaH gene detected from one sample $(0.79 \%)$ in this survey indicates the possibility of contamination by EIEC or Shigella, because this gene is a multicopy gene which is exclusively found in those pathogens [19]. The source of contamination is uncertain, but fecally contaminated water and unsanitary handling by food handlers are the probable causes of contamination. Previous report of S. sonnei outbreak in Spain was associated with regionally manufactured fresh pasteurized milk cheese that caused large outbreak affecting over 200 people in the region [20]. Epidemiological investigation suggests that infected employee at the cheese factory might have been the source of contamination.

Several prevalence studies conducted across the globe on these pathogens in natural cheeses show varying results from place to place. No pathogens such as E. coli O157:H7, L. monocytogenes, Salmonella, or Campylobacter was detected in US study [21]. In UK study, Salmonella was not detected; however, $2 \%$ of samples were at unsatisfactory level of 
Staphylococcus aureus, E. coli, and L. monocytogenes. Study in Italy showed that no L. monocytogenes was detected; however, high levels of $S$. aureus and E. coli were detected in particular samples [22]. In Spanish study, 2.4\% of samples were positive for STEC [23]. In Peru, 7.8\% of samples were positive for $E$. coli $\mathrm{O} 157: \mathrm{H7}[23,24]$. From our results and the fact that outbreaks of food borne pathogens related to consumption of cheese are not common in Japan, natural cheese produced in Hokkaido seems to be in relatively better hygienic status as compared to those produced in other countries mentioned above.

The outbreaks of food borne pathogens related to consumption of dairy products are not common in Japan so far. Several reports predict that the market for domestically produced natural cheese will continue to grow from year to year $[1,2]$. The average cheese consumption of the Japanese is about $2 \mathrm{~kg}$ a year per person, which is 10 times lower than those in European countries. This may account for lower incidence of foodborne outbreak associated with cheese. However, increase in consumption and production amounts may influence the risk of foodborne illness in future. Conducting similar survey in small and large scale on periodic basis would be important to ensure food safety of domestic natural cheese and to prevent possible incidence of foodborne pathogen outbreaks and related public health hazards.

In conclusion, the current result indicates that the microbiological quality and hygienic status of the natural cheese tested in this study was in the mostly fine and satisfactory status. This may be attributed to the required use of pasteurized milk for production of dairy products and implementation of good manufacturing and hygienic practices across all production stages from farm to table. The results from this study also suggest that current regulation and ministerial guidance would be considered appropriate for safe natural cheese production.

\section{Acknowledgments}

This work was supported by a grant from Ministry of Education, Culture, Sports, Science and Technology (MEXT), by a grant from Japan International Cooperation Agency (JICA) Advanced Research Course on International Animal Health, and by a grant from the Ministry of Health, Labor and Welfare. The authors are grateful to M. Kagawa, M. Yagihashi, and $\mathrm{K}$. Kanetake for their technical assistance.

\section{References}

[1] S. Gottet, The Japanese Cheese Market. Opportunities and Challenges, Swiss Business Hub Japan, 2011.

[2] B. Petlock, "Dairy and products Semi-annual. 2012 Japan milk and dairy products market outlook and 2011 situation summary update," Global Agricultural Information Network JA2011, USDA Foreign Agricultural Service, 2012.

[3] M. Kousta, M. Mataragas, P. Skandamis, and E. H. Drosinos, "Prevalence and sources of cheese contamination with pathogens at farm and processing levels," Food Control, vol. 21, no. 6, pp. 805-815, 2010.
[4] B. Swaminathan and P. Gerner-Smidt, "The epidemiology of human listeriosis," Microbes and Infection, vol. 9, no. 10, pp. 1236-1243, 2007.

[5] J. Y. D'Aoust, "Infective dose of Salmonella typhimurium in cheddar cheese," American Journal of Epidemiology, vol. 122, no. 4, pp. 717-720, 1985.

[6] M. J. Linnan, L. Mascola, X. D. L. Xiao Dong Lou et al., "Epidemic listeriosis associated with Mexican-style cheese," New England Journal of Medicine, vol. 319, no. 13, pp. 823-828, 1988.

[7] P. D. M. MacDonald, R. E. Whitwam, J. D. Boggs et al., "Outbreak of listeriosis among Mexican immigrants as a result of consumption of illicitly produced Mexican-style cheese," Clinical Infectious Diseases, vol. 40, no. 5, pp. 677-682, 2005.

[8] L. Honish, G. Predy, N. Hislop et al., "An outbreak of E. coli O15:H7 hemorrhagic colitis associated with unpasteurized gouda cheese," Canadian Journal of Public Health, vol. 96, no. 3, pp. 182-184, 2005.

[9] R. Pastore, H. Schmid, E. Altpeter et al., "Outbreak of Salmonella serovar Stanley infections in Switzerland linked to locally produced soft cheese, September 2006-February 2007," Euro Surveillance, vol. 13, no. 37, 2008.

[10] C. L. Baylis, "Raw milk and raw milk cheeses as vehicles for infection by Verocytotoxin-producing Escherichia coli," International Journal of Dairy Technology, vol. 62, no. 3, pp. 293-307, 2009.

[11] A. Okutani, Y. Okada, S. Yamamoto, and S. Igimi, "Overview of Listeria monocytogenes contamination in Japan," International Journal of Food Microbiology, vol. 93, no. 2, pp. 131-140, 2004.

[12] S. I. Makino, K. Kawamoto, K. Takeshi et al., "An outbreak of food-borne listeriosis due to cheese in Japan, during 2001," International Journal of Food Microbiology, vol. 104, no. 2, pp. 189-196, 2005.

[13] C. L. Gyles, "Shiga toxin-producing Escherichia coli: an overview," Journal of Animal Science, vol. 85, no. 13, pp. E45E62, 2007.

[14] Microbiology of Food and Animal Feeding Stuffs. Horizontal Method for the Detection and Enumeration of Listeria Monocytogenes. Part 1: Detection Method, ISO 11290-1, International Organization for Standardization, Geneva, Switzerland, 1996.

[15] W. H. Andrews and T. S. Hammack, Bacteriological Analytical Manual, revision A, chapter 5, 8th edition, 1998.

[16] P. Dixon, "European systems for the safe production of raw milk cheese," 2000, http://www.dairyfoodsconsulting.com/ pdf/EU_cheese_safety_report.pdf.

[17] P. L. Ruegg, "Practical food safety interventions for dairy production," Journal of Dairy Science, vol. 86, no. 1, pp. E1-E9, 2003.

[18] U.S. Department of Health and Human Services, "Grade A" Pasteurized Milk Ordinance, 2009 revision, Food and Drug Administration, 2009.

[19] M. J. C. van den Beld and F. A. G. Reubsaet, "Differentiation between Shigella, enteroinvasive Escherichia coli (EIEC) and noninvasive Escherichia coli," European Journal of Clinical Microbiology and Infectious Diseases, vol. 31, pp. 899-904, 2012.

[20] A. García-Fulgueiras, S. Sánchez, J. J. Guillén, B. Marsilla, A. Aladueña, and C. Navarro, "A large outbreak of Shigella sonnei gastroenteritis associated with consumption of fresh pasteurised milk cheese," European Journal of Epidemiology, vol. 17, no. 6, pp. 533-538, 2001. 
[21] J. C. Brooks, B. Martinez, J. Stratton, A. Bianchini, R. Krokstrom, and R. Hutkins, "Survey of raw milk cheeses for microbiological quality and prevalence of foodborne pathogens," Food Microbiology, vol. 31, pp. 154-158, 2012.

[22] G. M. Giammanco, A. Pepe, A. Aleo, V. D’Agostino, S. Milone, and C. Mammina, "Microbiological quality of Pecorino Siciliano "primosale" cheese on retail sale in the street markets of Palermo, Italy," New Microbiologica, vol. 34, no. 2, pp. 179-185, 2011.

[23] C. Vernozy-Rozand, M. P. Montet, M. Berardin, C. Bavai, and L. Beutin, "Isolation and characterization of Shiga toxinproducing Escherichia coli strains from raw milk cheeses in France," Letters in Applied Microbiology, vol. 41, no. 3, pp. 235241, 2005.

[24] I. Caro and M. R. García-Armesto, "Occurrence of Shiga toxinproducing Escherichia coli in a Spanish raw ewe's milk cheese," International Journal of Food Microbiology, vol. 116, no. 3, pp. 410-413, 2007. 

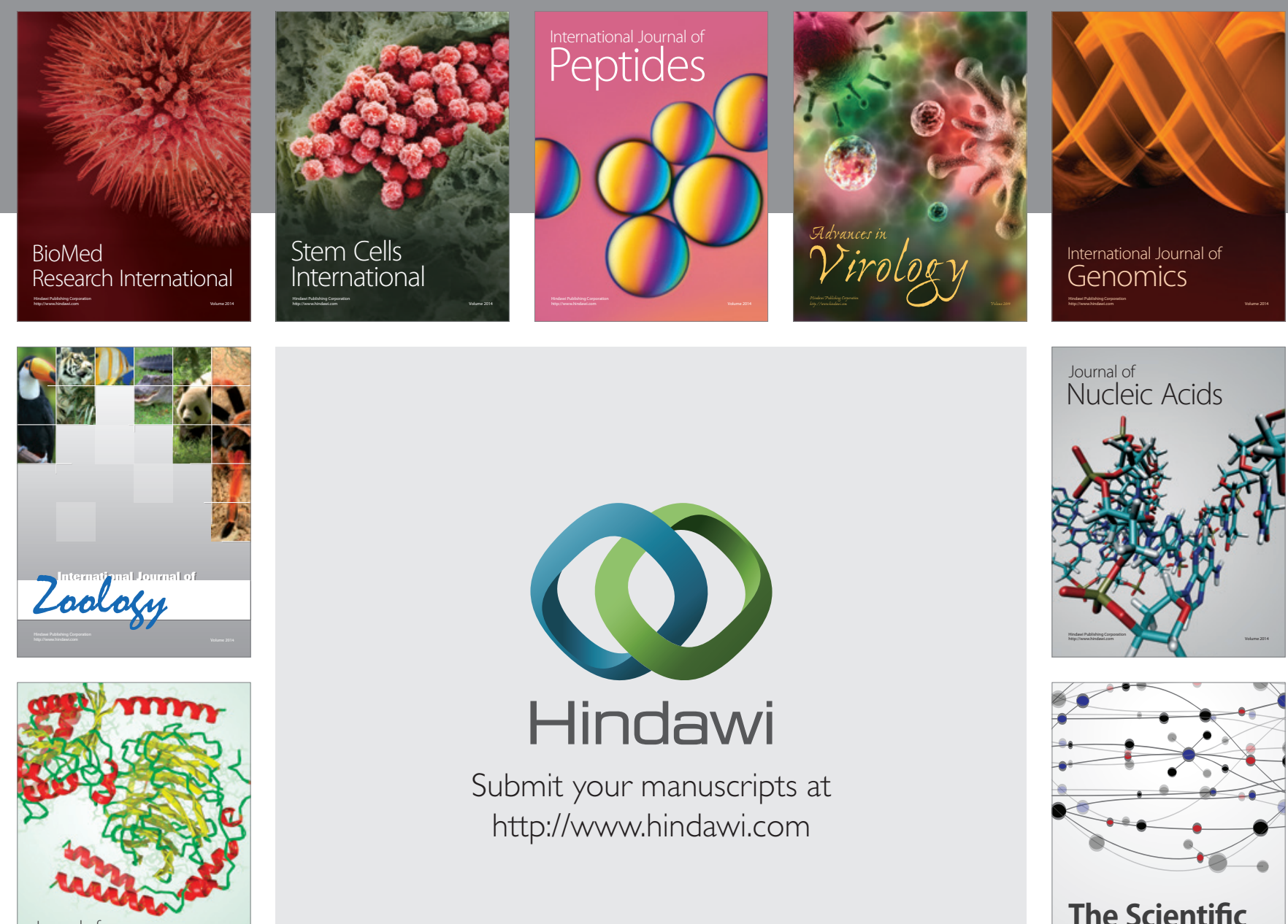

Submit your manuscripts at

http://www.hindawi.com

Journal of
Signal Transduction
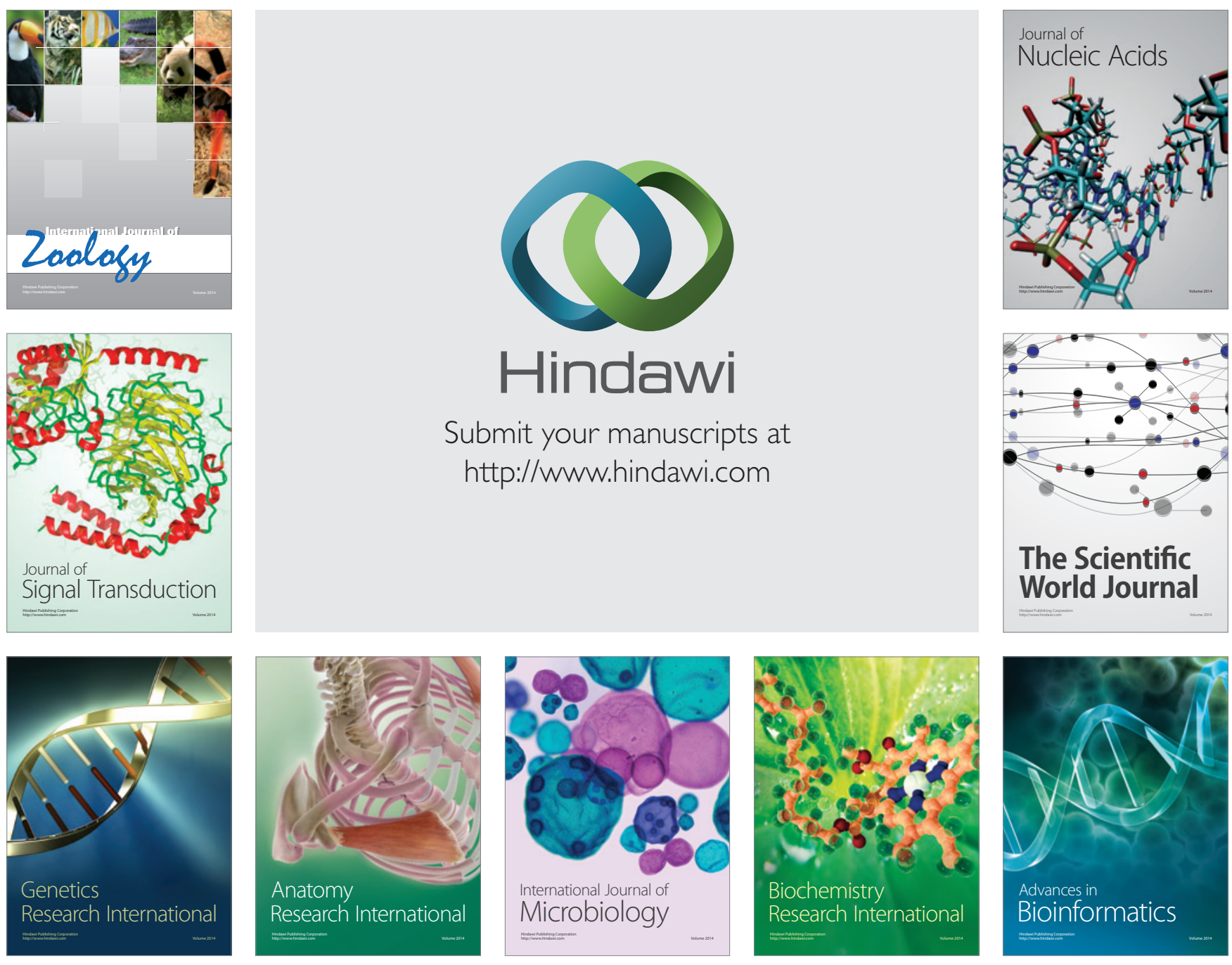

The Scientific World Journal
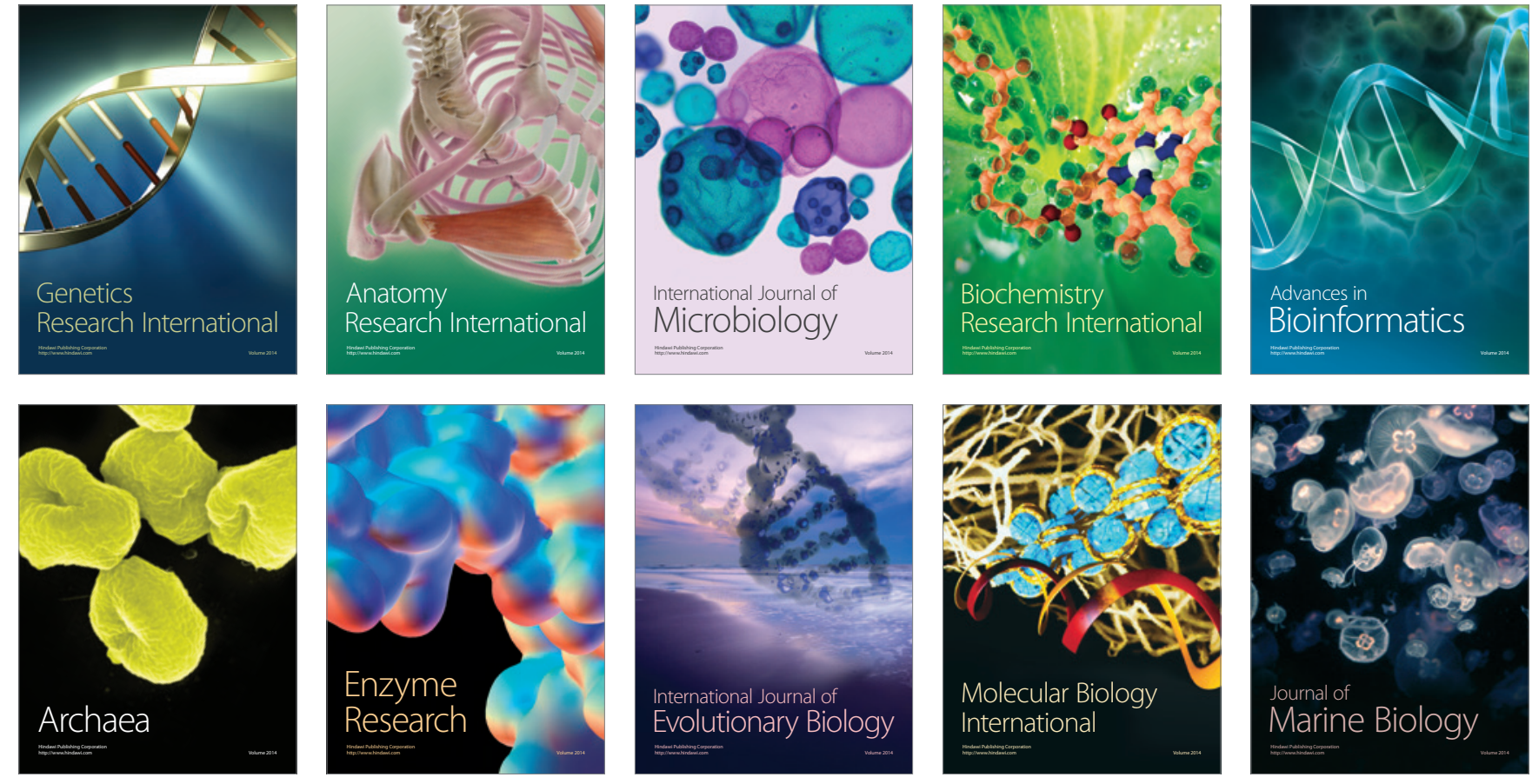